поволі накопичуючи досвід такої роботи, не можуть концентрувати та підтримувати на відповідному рівні свою увагу, у результаті- випускають з поля зору провідні ідеї, положення, гублять провідну думку, як підсумок - есе, наукова стаття, рецензія або інший науковий філологічний текст видаються їм складними та нецікавими. Тож розвиток рефлексивних умінь - конче потрібна робота, яка повинна розгортатися саме на тлі вивчення філологічних дисциплін.

\title{
Література
}

1. Богин Г. И. Филологическая герменевтика / Георгий Исаевич Богин - Калинин: КГУ, 1982. - 86 с. 2. Бродский И. А. Книга интервью / Иосиф Александрович Бродский. - [3-е изд., испр. и доп.]. - М. : Захаров, 2005. - 784 с. 3. Нургалеев В. Диалог культур как основа современной педагогической парадигмы / В. Нургалеев, Л. Барановская// Высшее образование в России. - 2004. - № 12. - С.48-51. 4. Сенько Ю. В. Гуманитарные основы педагогического образования: Курс лекций: [учеб. пособ. для студ. высш. пед. учеб. заведений] / Ю. В. Сенько. - М. : Изд. центр «Академия», 2000. - 240 с. 5. Сериков В. В. Личностный подход в образовании: концепции и технологии: [монографія]/ Владислав Владиславович Сериков.Волгоград: Перемена, 1994. - 152 с. 6. Polanyi М. The Foundations of freedom in Science / M. Polanyi // Physical Science and Human Values. - N.Y., 1969. - P. 125.

\section{ОСОБЛИВОСТІ ПРОФЕСІЙНОЇ ПІДГОТОВКИ ІНЖЕНЕРІВ У НІМЕЦЬКИХ ВНЗ У СИСТЕМІ ДУАЛЬНОЇ ОСВІТИ}

Гарасюта В. М. Особливості професійної підготовки інженерів у німецьких ВНЗ у системі дуальної освіти.

У статті висвітлюються основні питання організації навчання інженерів у німецьких ВНЗ у системі дуальної освіти. Розглянуто переваги професійної підготовки майбутніх фахівців у процесі дуального навчання. Подано вимоги до майбутніх інженерів 3 боку підприємств i навчальних закладів. Викладено можливості працевлаштування випускників.

Ключові слова: професійна освіта, дуальна освіта, професійна підготовка, інженер.

Гарасюта В. М. Особенности профессиональной подготовки инженеров в немецких вузах в системе дуального образования.

В статье освещаются основные вопросы организации обучения инженеров в немецких вузах в системе дуального образования. Рассмотрены преимущества профессиональной подготовки будущих специалистов в процессе дуального обучения. Представлены требования к будущим инженерам со стороны предприятий и учебных заведений. Изложены возможности трудоустройства выпускников.

Ключевые слова: профессиональное образование, дуальное образование, профессиональная подготовка, инженер.

Garasyuta V. M. Features of the professional training of engineers at German universities in the dual education system.

The article deals with the key questions of the organization of training engineers at German universities in the dual education system. The advantages of training future professionals in the process of dual training are considered. The requirements for future 
engineers from businesses and educational institutions are provided. The employability possibilities of graduates are set out.

Key words: vocational training, dual education, training, engineer.

На початку XXI століття в умовах глобалізації та інформатизації суспільства змінюються пріоритети професійної підготовки фахівців аграрного профілю. Ринок потребує докорінного підвищення якості професійної освіти, високого рівня кваліфікації, яку здобуває майбутній робітник. Гостро стоїть питання забезпечення конкурентоспроможності потенціалу фахівців на ринку праці. Свропейські країни, зокрема, Німеччина досягають покращення якості освіти шляхом модернізації змісту професійної підготовки. Тому вивчення досвіду цієї країни може стати поштовхом задля якісних змін у професійній освіті нашої країни.

Питання модернізації вищої освіти Німеччини $\epsilon$ актуальним для німецьких (П. Векс, О. Маасен, І. Мюскенс, Х. Фрідріх, А. Ханфт) та вітчизняних (А. Афанасьєв, В. Бойденко, В. Калашков, Б. Клименко, Г. Лучик, В. Миронов, В. Пусвацет та інші) дослідників. Модернізація професійної освіти стала об'єктом уваги українських (Н. Абашкіна, Л. Кнодель, М. Степко) та німецьких (А. Буш, У. Мюллер, А. Плегер, Л. Цибель) науковців.

Мета статmі - проаналізувати основні напрями модернізації змісту професійної підготовки інженерів аграрного профілю.

Актуальність дослідження розвитку професійної освіти в Німеччині визначається вагомими здобутками щодо підготовки кадрів для виробничих галузей i сфери обслуговування. Необхідність вивчення цього досвіду визначається також віднесенням Німеччини до найбільш економічно розвинених країн. Висока якість професійної підготовки німецьких фахівців має не лише давні традиції, але й стала однією 3 важливих умов її швидкого економічного відродження після другої світової війни.

За останні два десятиліття освітні реформи Німеччини були спрямовані, насамперед на вдосконалення системи професійної підготовки. Поступово здійснювався перехід до нових методів навчання. Модернізація системи освіти Німеччини в останнє десятиліття зумовлена трьома основними чинниками. Перший пов'язаний із необхідністю адаптації національної системи освіти до реалій i потреб постіндустріальної епохи, інтернаціоналізації та глобалізації освіти. Другий чинник визначив характер і зміст змін, що відбулися в системі освіти Німеччини. Третій фактор пов'язаний з особливостями державного устрою Німеччини.

На основі аналізу результатів модернізації професійної освіти у східних землях німецькі спеціалісти дійшли висновку, що професійна освіта перебуває в тісному зв'язку з організацією економіки країни, ситуацією, що складається на ринку праці й соціальним забезпеченням населення [1, с. 120].

Як наслідок, завдяки економічним показникам Німеччини система підготовки робітничих кадрів аграрного профілю в цій країні заслуговує на увагу багатьох спеціалістів. Подальша модернізація освіти в Німеччині проводилася в межах освітнього форуму, що проходив під егідою Конференції міністрів освіти й культури та за участю Спільної - федерально-земельної комісії із планування освіти і наукової роботи.

16 квітня 1997 року федеральний уряд ухвалив розширений законопроект, спрямований на реформування професійної освіти задля забезпечення іiі гнучкості, диференційованості й відкритості, що мало підвищити успішність професійної соціалізації. Вузька спеціалізація та лише базові знання 3 основних предметів не сприяють досягненню гідної професійної освіти й оптимального переходу до трудової діяльності. 
Переважна більшість молоді в Німеччині (близько 70 \%, або 2/3 всіх випускників) після закінчення школи навчаються одній із 350 професій, що має державну ліцензію, у межах дуальної системи, коли спеціальні теоретичні знання надаються у професійній школі, а практична підготовка здійснюється безпосередньо на робочому місці або в спеціальних навчальних майстернях на підприємстві або фірмі. Таке поєднання теорії та практики забезпечує високу кваліфікацію німецьких фахівців, що отримала визнання у всьому світі. Навчальні професії в межах дуальної системи затверджуються в тісній співпраці між федерацією, землями та соціальними партнерами і орієнтуються на вимоги ринку праці. Дуальна система Німеччини виникла як нова форма професійного навчання, організація якого передбачає надання теоретичної і практичної професійної підготовленості, а отже, утвердження провідного принципу - єдності індивідуалізації та інтелектуалізації професійного навчання - діяльнісної компетенції [2, с. 22-23].

Для надання дуальній системі більшої гнучкості розроблено навчальні програми за групами професій, що забезпечують можливість вибору професії та занять. У Німеччині дуальна система професійного навчання - це взаємодія двох самостійних в організаційному і правовому відношенні носіїв освіти в офіційно визнаних межах, тобто здійснюється відповідно до законодавства професійного навчання. Ця система охоплює два різні навчально-виробничі середовища - приватне підприємство й державну професійну школу, які діють разом для досягнення спільної мети- професійної підготовки учнів.

Процес надання освітніх послуг підприємством у межах дуальної системи регламентований законодавчо. Відповідно до $§ 25$ і 28 закону про професійну освіту навчальне підприємство може готувати фахівця тільки за визнаними державою професіями, список яких щорічно публікується федеральним Міністерством освіти і науки (Staatlich annerkannte Ausbildungsberufe). Усі професії поділені на групи.

Перед початком професійного навчання повинен бути укладений договір про професійну освіту між підприємством, яке навчає або направляє на навчання, а потім надає робочі місця, і студентом [3, с. 10].

3 початком виробничого навчання учень і навчальне підприємство наділяються певними правами і обов'язками, детально розписаними і закріпленими в Законі про професійну освіту.

Професійне навчання в дуальній системі розпочинається 3 випробувального терміну, тривалість якого складає 1-4 місяці $[4$, с. 20]. Цей час надається на визначення профпридатності учня. Протягом цього терміну навчальне підприємство може розірвати договір. Ініціатором розірвання договору може виступити й учень, якщо він дійде висновку про неправильність зробленого ним вибору [4, с. 22]. Якщо випробувальний термін пройдено успішно, учень продовжує своє навчання.

Регулярний щоденний процес навчання детально розписано в договорі. Розмежовують два типи організації процесу навчання в дуальній системі: одночасне навчання на підприємстві і в профшколі або навчання блоками, наприклад, місяць у профшколі змінюється місяцем практики на виробництві. На виробниче навчання відводиться приблизно 3-4 дні на тиждень, на навчання у профшколі припадає 1-2 дні.

Щорічно навчальне підприємство надає студентам відпустку, тривалість якої визначається їхнім віком: до18 років - 25 робочих днів, до 17 років - 27 робочих днів і до 16 років - 30 робочих днів. Під час відпустки учням заборонено вести будь-яку трудову діяльність. Оскільки учні залучені до виробничого процесу, навчальне підприємство виплачує їм щомісяця грошові винагороди, розмір яких залежить від тарифної сітки, прийнятої на підприємстві, віку учнів, обсягу виконуваних робіт, i вказується в договорі щодо професійного навчання. Якщо з винагороди відраховуються 
натуральні виплати, наприклад харчування, знімання житла тощо, то в будь-якому випадку має виплачуватися грошова винагорода не менше $25 \%$ від установленої суми [5, с. 143].

По завершенню процесу навчання складаються випускні іспити для присвоєння професійної кваліфікації. Після складання випускного іспиту компетентним органом видається екзаменаційне свідоцтво. Навчальні підприємства отримують свідоцтво, яке містить дані про вид, тривалість та мету професійного навчання, а також відомості про отримані професійні знання, уміння і навички.

Після закінчення навчання здебільшого учні, що проходили навчання на великих підприємствах, залишаються працювати далі, але в ситуації, коли навчальне підприємство не стає постійним місцем роботи, учні, зазвичай, без значних труднощів працевлаштовуються за отриманою спеціальністю.

Отже, основними напрямами конструктивних динамічних перетворень у професійній освіті Німеччини є якість на всіх рівнях підготовки, інноваційний розвиток суспільства на засадах конкурентоспроможності освіти, забезпечення рівного доступу до всіх ланок професійної освіти завдяки створенню великої кількості освітніх програм. Унаслідок удалих заходів, спрямованих на модернізацію освітньої системи, одним із головних досягнень ФРН $є$ підготовка кадрів, які беруть безпосередню участь у створенні матеріальних благ та наданні послуг, якісно задовольняючи потреби населення.

\section{Література}

1. Абашкіна Н. В. Принцип розвитку професійної освіти в Німеччині/ Н. В. Абашкіна. - К. : Вища школа, 1998. - 207 с. 2. Абашкіна Н. В. Принципи розвитку професійної освіти в Німеччині : [монографія]/ Н. В. Абашкіна. - К. : Вища школа, 1998. - 207 с. 3. Липкина И. Н. Система образования взрослых в Германии : [учеб.метод. пособие]/ И. Н. Липкина, В. П. Тарантей. - Гродно : ГрГУ, 2001. - 104 с. 4. Berufsbildungsgesetz (BBiG) - Закон о профессиональном образовании Германии [Электронный ресурс]. - Режим доступа: http://www.gesetze-im-internet. de/bundesrecht/bbig_2005/gesamt.pdf. 5. Торопов Д. А. Обеспечение качества профессионального образования в Германии : дис... д-ра пед. наук / Д. А Торопов; РАО Ин-т педагогики и психологии профессионального образования. - М., 2005. - 301 с. 6. Романов С. П. Дуальная система инженерно-педагогического образования / С. П. Романов // Образование и наука. - 2007. - № 5. - С. 54-63.

УДК 373.3.016 (520)

Оксана Гудовсек

\section{ОСОБЛИВОСТІ ЗМІСТУ ОСВІТИ В ПОЧАТКОВІЙ ШКОЛІ ЯПОНІї}

Гудовсек О. А. Особливості змісту освіти в початковій школі Японії.

У статті проаналізовано особливості навчання в сучасній початковій школі Японії. На основі аналізу змісту початкової освіти виокремлено найважливіші його складники, розкрито специфіку навчальних предметів. Визначено, що важливе місце у змісті освіти японських початкових шкіл займає моральне виховання, а також позакласна виховна робота, участь дітей у національних святах.

Ключові слова: зміст, початкова школа, навчання, моральне виховання, учні, програма. 